\title{
Migraine and Sleep Disorders: A Narrative Review
}

\author{
Wonwoo Lee, Min Kyung Chu \\ Department of Neurology, Severance Hospital, Yonsei University College of Medicine, Seoul, Korea \\ 편두통과 수면질환 \\ 이원우, 주민경 \\ 연세대학교 의과대학 세브란스병원 신경과학교실
}

Received November 5, 2020

Revised December 2, 2020

Accepted December 3, 2020

Address for correspondence

Min Kyung Chu, MD, PhD

Department of Neurology,

Severance Hospital,

Yonsei University

College of Medicine,

50-1 Yonsei-ro, Seodaemun-gu,

Seoul 03722, Korea

Tel: +82-2-2228-1600

Fax: +82-2-393-0705

E-mail: chumk@yonsei.ac.kr

Headaches and sleep problems are burdensome in daily life. They can co-occur and aggravate each other. The prevalence of sleep disorders is high in chronic headache and migraine patients, suggesting a close clinical relationship between these conditions. Structures from the brainstem to the cerebral cortex are related to sleep and headache modulation. In addition, various neurochemicals are related to and overlapped in the modulation of sleep and headache. In this paper, we briefly review the association between migraine and sleep disorders, including insomnia, sleep-related breathing disorders, central disorders of hypersomnolence, circadian rhythm sleep-wake disorder, parasomnias, and sleep-related movement disorders.

J Sleep Med 2020;17(2):101-107

Key Words: Sleep, Sleep disorders, Insomnia, Obstructive sleep apnea, Migraine, Restless legs syndrome.

\section{서 론}

편두통과 수면질환은 서로 밀접하게 관련되어 있다. 단면 연구에서 편두통환자에서는 수면질환이 더 많으며, 수면질 환 환자에서는 편두통이 더 많다. ${ }^{1,2}$ 추적연구에서도 수면질 환이 있는 경우에는 추후 편두통이 더 많이 발생하고, 편두 통이 있는 경우에도 추후 수면질환의 발생이 더 많다. 편두 통과 수면질환과의 밀접한 관계의 상호기전은 아직 밝혀지 지 않은 부분이 많다.

편두통과 수면은 모두 뇌줄기에서 대뇌겉질까지 광범위한 중추신경계 구조물과 신경전달물질이 관여하고 있다. 편두 통은 경막주변부 혈관을 포함한 통증에 민감한 구조물들의 자극에 의해 발생하여, 삼차신경경부신경복합체(trigeminocervical complex, TCC), 수도주위회백질(periagueductal gray matter), 시상하부(hypothalamus), 시상(thalamus), 대뇌피

This is an Open Access article distributed under the terms of the Creative Commons Attribution Non-Commercial License (https://creativecommons.org/licenses/by-nc/4.0) which permits unrestricted non-commercial use, distribution, and reproduction in any medium, provided the original work is properly cited.
질에 의해 전달과 조절이 이루어진다. ${ }^{3}$

수면에서 시상하부의 시신경교차핵(suprachiasmatic nucleus)은 수면의 일주기리듬을 생성하고, 뇌줄기에서 시작하 는 상승망상활성계(ascending reticular activating system)는 각성을 촉진하며, 시상하부의 복외측시각교차전핵(ventrolateral preoptic nucleus)은 각성을 억제하는 작용을 하여, 수 면과 각성을 조절한다. 이러한 편두통과 수면의 조절기전은 서로 중첩되는 부분이 있어 상호영향을 가질 것으로 생각되 고 있다. ${ }^{4}$ 본 논문에서는 편두통과 수면질환과의 연관성에 대해 기술하고자 한다.

\section{본 론}

\section{편두통과 수면의 구조적 및 신경화학적 연관성}

대뇌피질, 시상, 시상하부, 뇌줄기핵은 모두 통증의 전달과 수면의 조절에 관여한다. 각 구조의 통증전달과 수면에 관련 된 기능은 Fig. 1에 정리하였다. 편두통과 수면에서 공통으로 작용하는 신경전달물질로는 아데노신(adenosine), 오렉신 


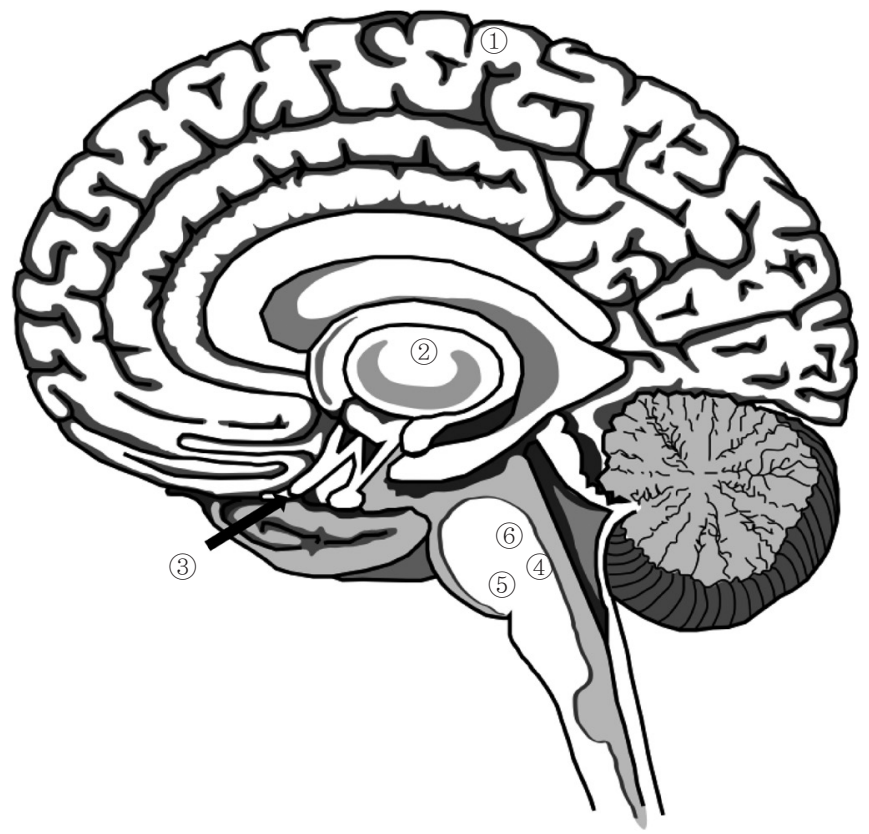

\begin{tabular}{|c|c|c|}
\hline Structure & Migraine & Sleep \\
\hline (1) Cortex & $\begin{array}{l}\text { Pain processing: ascending thalamo-cortical } \\
\text { projections synapse on a diffuse network } \\
\text { of cortical regions including primary and } \\
\text { secondary motor somatosensory and visual } \\
\text { cortex for pain processing } \\
\text { Pain modulation: modulation of pain through } \\
\text { descending direct and indirect projections } \\
\text { from the cortex to the TCC }\end{array}$ & $\begin{array}{l}\text { Promotion of wakefulness through ascending } \\
\text { inputs from monoaminergic neurons, } \\
\text { hypothalamus, and basal forebrain }\end{array}$ \\
\hline (2) Thalamus & $\begin{array}{l}\text { Processing and transmission of nociceptive } \\
\text { information from the TCC }\end{array}$ & $\begin{array}{l}\text { Promotion of wakefulness of sub-cortical } \\
\text { sleep-wake inputs }\end{array}$ \\
\hline \multirow{3}{*}{$\begin{array}{l}\text { (3) Hypothalamus } \\
\text { Posterior hypothalamus } \\
\text { (dopaminergic) } \\
\text { Lateral hypothalamic (orexin) }\end{array}$} & $\begin{array}{l}\text { Processing and modulation of pain from } \\
\text { ascending pathway from the brainstem nuclei } \\
\text { and the TCC }\end{array}$ & $\begin{array}{l}\text { Promotion of wakefulness, regulation of } \\
\text { circadian control of sleep-wake transition }\end{array}$ \\
\hline & $\begin{array}{l}\text { The dopaminergic A11 nucleus is responsible } \\
\text { for premonitory migraine symptoms }\end{array}$ & $\begin{array}{l}\text { Promotion of wakefulness through the } \\
\text { activation of the brainstem monoaminergic } \\
\text { system, the basal forebrain, and the cortex }\end{array}$ \\
\hline & $\begin{array}{l}\text { Orexinergic neurons facilitate or inhibit TCC } \\
\text { nociception by receptor specific pathways }\end{array}$ & $\begin{array}{l}\text { Control of sleep-wake transition: participate } \\
\text { to the "flip-flop" system for sleep-wake } \\
\text { transition }\end{array}$ \\
\hline $\begin{array}{l}\text { Brainstem } \\
\text { (4) Periaqueductal gray (dopamine) } \\
\text { (5) Dorsal raphe nucleus (serotonin) } \\
\text { (6) Locus coeruleus (norepinephrine) }\end{array}$ & $\begin{array}{l}\text { Pain transmission from afferent fibers of TCC } \\
\text { to the thalamus } \\
\text { Pain modulation through descending inputs } \\
\text { from thalamus and hypothalamus }\end{array}$ & $\begin{array}{l}\text { Promotion of wakefulness: ascending } \\
\text { activating pathways projecting from the } \\
\text { brainstem to the thalamus and basal forebrain } \\
\text { Stabilization of the waking state: receive the } \\
\text { orexinergic excitatory projections and sends } \\
\text { inhibitory inputs to the sleep promoting } \\
\text { VLPO to reinforce wakefulness } \\
\text { Control of the transition to sleep: inhibition } \\
\text { of these nucleus by the VLPO promotes sleep } \\
\text { Noradrenergic and serotonergic neurons } \\
\text { inhibit the REM sleep }\end{array}$ \\
\hline
\end{tabular}

Figure 1. Shared anatomic structures between migraine and sleep. TCC: trigeminocervical complex, VLPO: ventrolateral preoptic nucleus. 
(orexin), 멜라토닌(melatonin)이 있다. 통증과 수면에 관련된 아데노신, 오렉신, 멜라토닌의 기능은 Table 1 에 정리하였다.

\section{불면증}

불면증은 흔한 수면질환으로 전체 인구의 약 $10 ~ 15 \%$ 가 만 성 불면증으로 않고 있는 것으로 추산된다. 불면증과 편두통 의 관련성은 역학적 연구에서 관찰되었다. 단면연구에서 불 면증환자에서는 편두통 유병률이 높으며, 편두통환자에서 는 불면증 유병률도 비편두통인에 비해 더 높다. 두통이 1 달 에 15 일 이상 지속되는 만성편두통에서는 불면증 유병률이 삽화편두통에 비해 더 증가하여 약 30 40\%에 이른다. 편두 통환자에서 불면증이 동반되면 편두통 강도가 더 높고, 두통 으로 인한 통증, 사회기능, 역할기능, 인지기능, 심리적 고통 등의 다양한 영향을 평가하는 척도인 두통영향검사 $\left(\mathrm{Head}^{-}\right.$ ache Impact Test-6) 점수가 더 높으며, 편두통 빈도가 더 자주 있고, 만성편두통으로의 변환 위험이 더 높았다. ${ }^{1,5-7}$ 이 러한 편두통환자에서 불면증의 동반은 우울과 불안의 동반 만으로는 설명되지 않는다. 89

추적연구에서 불면증이 있으면 이후 편두통 발병률이 높 고, 편두통이 있으면 이후 불면증 발병률이 증가한다. 대규모 인구기반연구인 HUNT-2와 HUNT-3 연구에서 두통이 없 고 불면증이 있는 사람은 두통과 불면증이 모두 없는 사람에 비해 11 년 뒤에 편두통 발생률이 더 높았다. ${ }^{6}$ 유사하게 편두 통이 있는 사람은 11 년 뒤에는 새롭게 불면증이 발생할 위험 이 편두통이 없는 사람에 비해 약 2 배 더 높았다. ${ }^{7}$ 이러한 관 계는 편두통 뿐만 아니라 모든 원발두통에서도 불면증과 상 호 발생 위험의 증가가 관찰되었다. ${ }^{67}$ 추적연구에서 두 질환 의 존재가 상호 질환의 발병률을 높이는 것을 양방향 동반 이환이라고 하며, 양방향 동반이환은 병리기전을 공유한다 고 생각된다. ${ }^{10}$ 따라서 불면증과 두통은 병리기전을 공유함을 시사한다.

불면증이 동반된 편두통환자에서 수면제인 eszopiclone으 로 치료할 경우 야간 각성, 주간 졸림 증상이 호전되었지만,
두통의 빈도와 강도는 변화가 없었다. ${ }^{11}$ 불면증이 동반된 편 두통환자에서 불면증 인지행동치료를 시행한 경우에는 편 두통 빈도가 매월 약 6.2 회 정도 감소시킨다고 보고되었다. ${ }^{12}$ 따라서 불면증 인지행동치료는 만성편두통의 비약물적 치 료로 고려할 수 있다.

수면중의 편두통 발작은 렘수면기에 더 많이 나타난다. ${ }^{13}$ 이러한 렘수면과 편두통 발작과의 관계는 시상하부와 뇌줄 기핵의 수면-각성조절에 장애가 있음을 시사한다. ${ }^{14,15}$ 편두 통과 불면증은 두 질환 모두 시상하부와 뇌줄기핵 기능이상 에 의해 유발되므로, 두 질환의 밀접한 관계는 시상하부와 뇌줄기핵의 기능이상에 기인한 것으로 생각되어왔다.

편두통과 불면증의 관계를 정리하면, 기존의 연구에서 지 속적으로 불면증와 편두통은 우울 및 불안과 무관하게 양방 향 동반이환이 보고되었으며, 이는 두질환 병리기전의 공유 를 시사한다. 불면증은 편두통의 발생, 악화, 만성편두통으로 의 변화와 밀접한 관계가 있다. 편두통이 있는 사람은 불면 증을 가질 위험이 더 높다. 그러나 이러한 관계는 편두통에 특이한 것은 아니며, 전체 두통과 불면증이 관련되어 있다. 임상의사는 두통환자를 치료할 경우 불면증이 동반되어 있 는지 특별히 평가해야 할 것이며, 만약 불면증이 있다면 불 면증 치료를 적극적으로 고려해야 할 것이다. 아울러 최근 불면증의 인지행동치료로 편두통의 호전이 보고되어, 편두 통 치료의 일환으로도 인지행동치료를 포함한 비약물적인 치료도 적극적으로 고려해야 한다.

\section{수면관련호흡장애}

수면관련호흡장애는 수면중에 반복적인 호흡 이상이 나타 나며, 이로 인해 수면의 분절화와 헤모글로빈 산소포화도의 감소가 일어난다. 수면관련호흡장애는 성인 인구의 약 $20 \%$ 에서 나타나는 흔한 질환이며 여성에 비해 남성에서 위험도 가 2.0 3.7배 더 증가한다. ${ }^{16,17}$

수면무호흡은 무호흡 또는 저호흡에 의해 반복적인 공기 흐름의 중단으로 인해 산소포화도가 감소하고 수면의 분절

Table 1. Shared neurotransmitter functions between migraine and sleep

\begin{tabular}{lll}
\hline Neurotransmitters & \multicolumn{1}{c}{ Migraine } & \multicolumn{1}{c}{ Sleep } \\
\hline Adenosine & $\begin{array}{l}\text { Inhibit pain processing through A1 receptor in spinal cord } \\
\text { Inhibit orexin neurons }\end{array}$ & $\begin{array}{l}\text { Promotion of sleepiness via activation of A1 receptor } \\
\text { in basal forebrain } \\
\text { Promote sleep via activation of A2a receptor } \\
\text { Orexin }\end{array}$ \\
& $\begin{array}{l}\text { Orexin A inhibits pain transmission whereas Orexin B } \\
\text { promotes pain transmission. }\end{array}$ & $\begin{array}{l}\text { Promote wakefulness } \\
\text { Orexin receptor 1: high affinity to orexin A }\end{array}$ \\
& Orexin receptor 2: high affinity to orexin B & \\
Melatonin & Inhibit pain transmission & Promote sleepiness \\
\hline
\end{tabular}


을 특징으로 한다. 이러한 사건(event)은 산호포화도의 감소 를 유발하고, 짧은 각성으로 인해 중단된다. 수면무호흡환자 에서는 $29 \%$ 에서 아침 기상시의 두통, $15 \%$ 에서 긴장형두통, $8 \%$ 에서 편두통을 보고하였다. ${ }^{18}$ 수면무호흡의 유병률은 편 두통과 비편두통에서 의미있는 차이는 관찰되지 않았다. ${ }^{19}$ 수면다원검사를 시행하는 환자에서 조사한 후향적 연구에서 만성편두통의 존재는 수면무호흡의 존재와 의미있는 관계가 있었다..$^{20}$ 수면무호흡이 동반된 편두통환자에서 지속적양압 기로 수면무호흡을 치료한 경우에는 수면의 질이 호전되고 편두통빈도의 호전(월 당 5.8 일에서 0.1 일), 편두통 기간의 감소, 통증 강도의 감소, 두통으로 인한 장애일수 감소, 급성 기약물 사용의 감소가 관찰되었다. ${ }^{21}$

비만은 수면무호흡 이외에도 만성편두통으로의 변환의 위 험인자이다. ${ }^{22}$ 비만은 수면무호흡의 중요한 악화인자로 비만 인 경우에는 수면무호흡 유병률이 $45 \%$ 로 증가한다. 경도의 수면무호흡환자에서 $10 \%$ 체중 증가는 수면무호흡의 악화가 약 6 배 증가하며, $10 \%$ 체중 감소는 수면무호흡 심각도의 약 $20 \%$ 가 감소한다. ${ }^{23}$ 수면무호흡, 비만 그리고 편두통의 밀접 한 관계는 추후 수면무호흡과 편두통에서 비만의 역할에 대 한 추가 연구가 필요함을 시사한다.

수면관련호흡장애와 두통의 관계를 정리하면, 아침두통은 수면무호흡에서 흔히 보고되고 있지만, 수면무호흡과 편두 통의 의미있는 관계는 보고되지 않았다. 그러나 수면무호흡 은 편두통 만성화의 의미있는 인자로는 보고되어, 편두통이 있는 사람에서 수면무호흡이 있는 경우에는 양압기 치료 등 의 적극적인 치료가 필요하다. 최근에 두통이 발생 또는 기존 두통의 악화가 나타나며, 반복적인 코골이와 같이 수면무호 흡을 시사하는 증상이 있는 경우에는 수면관련호흡장애 존 재의 가능성을 고려하여 수면다원검사와 설문지 등을 이용 하여 평가를 진행해야 할 것이다.

\section{수면관련운동질환}

수면관련운동질환은 일정한 형태의 단순한 반복운동이 수 면중에 나타나서 수면장애를 유발하는 수면질환을 말한다. 가장 흔한 수면관련운동질환은 하지불안증후군이 있다. 하 지불안증후군은 사지를 움직이고 싶은 느낌과, 쉬거나 가만 히 있을 때 주로 나타나는 불편한 느낌, 그리고 사지의 움직 임에 의해 증상이 일부 또는 완전히 소실되는 것을 특징으로 한다. ${ }^{24}$ 하지불안증후군은 자주 주기하지운동증과 동반되어 나타난다. 일반 인구집단에서 하지불안증후군의 유병률은 5.0 14.3\%인 흔한 질환이다. ${ }^{25}$ 하지불안증후군에서 흔한 편 두통과의 동반이환은 여러 연구에서 반복적으로 관찰되었 다. 편두통에서 하지불안증후군의 유병률은 12.6 53.2\%로
증가하며, 하지불안증후군이 동반된 편두통은 그렇지 않은 경우에 비해 두통 일수, 두통 강도, 두통으로 인한 영향이 더 크다. $26-29$ 하지불안증후군에서도 편두통 유병률이 12.6 53.2\% 로 하지불안증후군이 없는 경우보다 더 증가되어 있다. 26-28,30

편두통과 하지불안증후군의 동반은 편두통 빈도와 밀접하 게 관련되어 있다. 편두통 빈도가 높으면 하지불안증후군 유 병률이 더 높으며, 1달에 두통이 15일 이상인 만성편두통의 경우에는 삽화편두통에 비해 더 흔하다(34.3\% vs. $16 \%){ }^{31}$ 하 지불안증후군과 삼환계항우울제, 선택세로토닌재흡수억제 제(selective serotonin reuptake inhibitor), 세로토닌-노르에 피네프린재흡수억제제(serotonin-norepinephrine reuptake inhibitor)의 사용과 관련이 있다고 보고되었으나, 미국수면의 학회(American Academy of Sleep Medicine)에서는 하지불 안증후군에서 항우울제 사용의 제한에 대한 특별한 기술은 없다. ${ }^{32}$ 2016년 International Restless Legs Syndrome Study Group에서는 항우울제를 포함한 외부인자에 의한 하지불안 증후군 증세 악화가 가능함이 기술되어 있다. ${ }^{33}$

하지불안증후군과 편두통의 동반이환은 시상하부의 A11 핵의 도파민 기능이상으로 생각되고 있다. 편두통의 전구기 (premonitory phase)와 두통기(headache phase)에서 도파민 작용제에 대한 과민증상인 하품, 구역, 졸림, 기분장애, 민감 함 등이 나타나며, 도파민억제제에 의해 이러한 증상은 회복 된다. ${ }^{34-36}$ 도파민억제제에 의한 편두통의 소화기증세의 호전 은 도파민이 편두통 병리기전에서 중요한 역할을 함을 시사 한다. 하지불안증후군이 동반된 편두통환자에서 도파민과 관련된 전구증상인 하품, 구역, 졸림의 빈도가 하지불안증후 군이 동반되지 않는 편두통보다 더 높음은 하지불안증후군과 편두통 병리기전에서 도파민 작용의 하나의 증거가 된다. ${ }^{37}$

수면관련운동질환에서는, 많은 연구에서 일관되게 하지불 안증후군환자에서 편두통 유병률 증가와 편두통환자의 하 지불안증후군 유병률 증가가 관찰되었다. 편두통환자에서 하지불안증후군이 동반된 경우에는 편두통 증상의 악화와 동반되므로 편두통환자를 평가할 경우 하지불안증후군 존재 여부를 평가할 필요가 있다. 편두통환자에서 하지불안증후 군이 동반된 경우에는 치료가 필요하다. 편두통환자에서 하 지불안증후군의 적절한 치료는 편두통 증상의 호전을 기대할 수 있다. 아울러 편두통환자에서 항우울증 약물치료를 할 경 우에는 하지불안증후군 악화의 가능성을 유의하여야 한다.

\section{중추기원의 과다졸림}

중추기전의 과다졸림은 야간의 수면장애나 일주기이상에 기인하지 않는 신경계이상에 의한 과다졸림이 있는 경우를 말한다. 대표적인 질환은 기면증(narcolepsy)과 특발과다수 
면(idiopathic hypersomnia)이 있다.

기면증은 유병률이 $0.025 ~ 0.05 \%$ 정도로 아동기 초기부터 50 대까지 나타나는 질병이며, 15 세와 35 세에서 유병률이 2번 의 최고점을 보인다. ${ }^{38}$ 기면증환자에서 조사한 병원기반연구 에서는 편두통 유병률이 $37 \%$ 정도로 증가되며, 기면증환자 에서 편두통 유병률 증가는, 기면증 발생이 증가하는 15 세부 터 현저하게 나타났다. ${ }^{39,40}$ 다른 연구에서도 기면증(23.5\%)과 특발과다수면(41.2\%)을 가진 환자에서 편두통 유병률의 증 가가 관찰되었다. 그러나 긴장형두통은 기면증과 특발과다 수면환자에서 대조군에 비해 증가가 관찰되지 않았다. ${ }^{41}$

최근 연구에서는 오렉신 시스템의 이상으로 편두통과 기 면증의 관계를 설명해주고 있다. 오렉신은 시상하부에서 분 비되고 수면-각성 주기의 조절과 자율신경계 항상성 유지의 기능을 한다. 시상하부는 오렉신A와 B 두 종류의 오렉신을 분비하며, 오렉신 수용체는 1형(OX1R)과 2형(OX2R)의 2가 지가 존재한다. ${ }^{42}$ 오렉신은 각성을 증가시켜주는 역할을 하 며, 아울러 일주기의 안정성을 유지시켜주는 역할을 한다. 탈력발작을 동반한 기면병 1형에서는 뇌척수액에서 오렉신 의 감소가 관찰된다. 동물 실험에서 오렉신A를 시상하부 뒤 쪽에 투여하면 경막이나 피부의 자극으로 TCC에서 발생하 는 통각의 전달이 억제된다. 반대로 오렉신B는 $\mathrm{TCC}$ 에서 전 달되는 통각을 촉진한다. ${ }^{43}$ 이러한 소견을 볼 때 아직까지 임 상적 연구는 부족하지만, 오렉신 조절의 기능이상이 수면 뿐 만 아니라 통증의 조절이상에도 관여하여 기면증과 편두통 의 동반이환을 유발한다고 생각된다. 오렉신억제제인 $\mathrm{su}^{-}$ vorexant는 불면증의 치료로 미국 FDA에서 허가되었으며, 편두통의 치료에도 효과가 있음이 보고되었다. ${ }^{44}$

편두통환자에서 특발과다수면은 기면증과 함께 유병률이 증가한다고 보고되었으나, 그 기전은 아직 밝혀진 바가 적다. ${ }^{41}$

\section{하루주기리듬수면각성장애}

하루주기리듬수면각성장애는 내인성의 하루주기리듬 체 계의 변경, 내인성 하루주기리듬과 개인의 신체적 환경, 또 는 사회/근무 일정에 의해 요구되는 수면-각성 일정 간의 불 일치로 인해, 수면-각성 리듬장애가 만성적이고 반복적으로 나타나는 상태를 말한다. ${ }^{24,45}$ 노르웨이에서 교대근무를 하는 간호사를 대상으로한 연구에서 교대근무장애(shift working disorder)가 있는 경우에 편두통[odds ratio(승산비) 1.60], 고 빈도두통(승산비 2.04), 만성두통(승산비 2.45)의 빈도가 더 증가하였다. 야간교대근무가 있는 경우에는 긴장형두통의 유병률이 더 증가하였다. ${ }^{46}$

현재 하루주기리듬수면각성장애와 편두통과의 관계에 대 한 자료는 많지 않다. 다양한 기준의 하루주기리듬수면각성
장애는 편두통과의 관계파악을 힘들게 한다. 향후 일관된 진 단기준을 바탕으로 연구가 진행되어야 할 것이다. 하루주기 리듬수면각성장애와 편두통과의 관계파악은 편두통의 발 생, 만성화 등에 시간 일정이 어떤 역할을 하는지에 대한 이 해를 높혀줄 것이다.

\section{사건수면}

사건수면은 잠에 빠져들 때, 자고 있을 때, 혹은 잠에서 깨 어날 때 원하지 않게 발생하는 신체적 사건이나 경험이다. 사건수면은 비렘수면이나 렘수면 동안, 혹은 수면으로부터 또는 수면으로 이행하는 단계에서 나타날 수 있다. ${ }^{24,45}$

렘수면행동장애(REM sleep behavior disorder, RBD)와 편두통과의 관계를 조사한 Suzuki 등의 연구는, RBD가 있는 경우에는 편두통 유병률이 $24.2 \%$ 로 대조군의 $14.3 \%$ 에 비해 증가를 보고하였다. ${ }^{47}$ 편두통과 수면장애의 동반이환을 조사 한 대규모 연구에서 편두통을 가진 사람은 대조군에 비해 유 아기에 악몽을 경험하는 비율이 더 높았으며, 이러한 관계는 불안이나 우울과 관련은 없었다. ${ }^{8}$ 몽유병환자에서도 모든 형 태의 두통과 편두통이 더 많았는데, 이는 우울과 불안의 동 반과는 무관하였다. ${ }^{48}$ 다른 연구에서도 편두통을 가진 사람 은 유아기에 몽유병을 경험하는 비율이 더 높았다.

세로토닌 시스템이 각성-수면에 관여하며, 편두통 병리기 전과도 관련이 있어, 세로토닌 시스템의 기능이상이 사건수 면과 편두통의 동반이환 관계를 설명하는 가설로 제시되고 있다. 최근의 연구에서 오렉신 뉴런이 세로토닌 뉴런이 존재 하는 솔기핵(raphe nucleus)에 투사되어, 세로토닌 작용에 영향을 주어 수면과 통증조절에 관여함이 보고되었다. ${ }^{49}$

기존의 연구결과에서 몽유병과 편두통의 의미있는 관계가 보고되었다. 그러나 성인에서 다른 사건수면과 편두통의 관 계는 아직 자료가 적어 명확하지 않다. ${ }^{50}$

\section{결 론}

기존의 역학, 병원기반 그리고 실험연구에서 다양한 수면 질환과 편두통의 밀접한 관계가 보고되었다. 그러나 이러한 관계는 다양하고 복합하며 아직 밝혀지지 않는 부분이 많다. 특히 해부학 및 신경전달물질 연구는 수면질환과 편두통의 상관관계를 이해하는 중요한 결과를 제시할 것이다. 비록 수 면질환에 따라 편두통과 관계는 다양하지만, 대부분의 경우 에 수면질환은 편두통이 있는 사람에서 더 증가하고, 수면질 환이 동반된 경우에는 편두통의 증상이 더 심해진다. 따라서 편두통환자를 평가할 경우에는 수면질환의 평가도 동반해 야 할 것이다. 


\section{Acknowledgments}

This study was financially supported by the "Dongwha" Faculty Research Assistance Program of Yonsei University College of Medicine (62018-0172).

\section{Conflicts of Interest}

Min Kyung Chu was a site investigator for a multi-center trial sponsored by Otsuka Korea, Novartis, International AG, and Eli Lilly and Co. He functioned as an advisory member for Teva, and received lecture honoraria from Allergan Korea, Handok-Teva, and Yuyu Pharmaceutical Company over the past 24 months. He received grants from the Yonsei University College of Medicine (2018-32-0037) and National Research Foundation of Korea (2019R1F1A1053841). Wonwoo Lee has nothing to declare.

\section{ORCID iDs}

$\begin{array}{ll}\text { Wonwoo Lee } & \text { https://orcid.org/0000-0002-0907-4212 } \\ \text { Min Kyung Chu } & \text { https://orcid.org/0000-0001-6221-1346 }\end{array}$

\section{Author Contributions}

Conceptualization: Min Kyung Chu. Data curation: Wonwoo Lee, Min Kyung Chu. Formal analysis: Min Kyung Chu. Funding acquisition: Min Kyung Chu. Investigation: Min Kyung Chu. Methodology: Min Kyung Chu. Project administration: Min Kyung Chu. Resources: Wonwoo Lee, Min Kyung Chu. Software: Wonwoo Lee, Min Kyung Chu. Supervision: Min Kyung Chu. Validation: Min Kyung Chu. Visualization: Min Kyung Chu. Writing_original draft: Wonwoo Lee. Writing_original draft: Min Kyung Chu.

\section{REFERENCES}

1. Kim J, Cho SJ, Kim WJ, Yang KI, Yun CH, Chu MK. Insomnia in probable migraine: a population-based study. J Headache Pain 2016;17: 92. https://doi.org/10.1186/s10194-016-0681-2.

2. Song TJ, Cho SJ, Kim WJ, Yang KI, Yun CH, Chu MK. Poor sleep quality in migraine and probable migraine: a population study. J Headache Pain 2018;19:58. https://doi.org/10.1186/s10194-018-0887-6.

3. Goadsby PJ, Charbit AR, Andreou AP, Akerman S, Holland PR. Neurobiology of migraine. Neuroscience 2009;161:327-341. https://doi. org/10.1016/j.neuroscience.2009.03.019.

4. Fuller PM, Gooley JJ, Saper CB. Neurobiology of the sleep-wake cycle: sleep architecture, circadian regulation, and regulatory feedback. J Biol Rhythms 2006;21:482-493. https://doi.org/10.1177/0748730406294627.

5. Kim J, Cho SJ, Kim WJ, Yang KI, Yun CH, Chu MK. Impact of migraine on the clinical presentation of insomnia: a population-based study. $J$ Headache Pain 2018;19:86. https://doi.org/10.1186/s10194-018-0916-5.

6. Odegård SS, Sand T, Engstrøm M, Stovner LJ, Zwart JA, Hagen K. The long-term effect of insomnia on primary headaches: a prospective population-based cohort study (HUNT-2 and HUNT-3). Headache 2011; 51:570-580. https://doi.org/10.1111/j.1526-4610.2011.01859.x.

7. Ødegård SS, Sand T, Engstrøm M, Zwart JA, Hagen K. The impact of headache and chronic musculoskeletal complaints on the risk of insomnia: longitudinal data from the Nord-Trøndelag health study. $J$ Headache Pain 2013;14:24. https://doi.org/10.1186/1129-2377-14-24.

8. Vgontzas A, Cui L, Merikangas KR. Are sleep difficulties associated with migraine attributable to anxiety and depression? Headache 2008; 48:1451-1459. https://doi.org/10.1111/j.1526-4610.2008.01175.x.

9. Yeung WF, Chung KF, Wong CY. Relationship between insomnia and headache in community-based middle-aged Hong Kong Chinese women. J Headache Pain 2010;11:187-195. https://doi.org/10.1007/ s10194-010-0199-y.

10. Zhang Q, Shao A, Jiang Z, Tsai H, Liu W. The exploration of mechanisms of comorbidity between migraine and depression. J Cell Mol Med 2019;23:4505-4513. https://doi.org/10.1111/jcmm.14390.
11. Spierings EL, McAllister PJ, Bilchik TR. Efficacy of treatment of insomnia in migraineurs with eszopiclone (Lunesta ${ }^{\circledR}$ ) and its effect on total sleep time, headache frequency, and daytime functioning: a randomized, double-blind, placebo-controlled, parallel-group, pilot study. Cranio 2015;33:115-121. https://doi.org/10.1179/0886963414Z.00000000084.

12. Smitherman TA, Kuka AJ, Calhoun AH, et al. Cognitive-behavioral therapy for insomnia to reduce chronic migraine: a sequential Bayesian analysis. Headache 2018;58:1052-1059. https://doi.org/10.1111/ head.13313.

13. Dexter JD, Weitzman ED. The relationship of nocturnal headaches to sleep stage patterns. Neurology 1970;20:513-518. https://doi.org/10.1212/ wnl.20.5.513.

14. Vgontzas A, Pavlović JM. Sleep disorders and migraine: review of literature and potential pathophysiology mechanisms. Headache 2018; 58:1030-1039. https://doi.org/10.1111/head.13358.

15. Tiseo C, Vacca A, Felbush A, et al. Migraine and sleep disorders: a systematic review. J Headache Pain 2020;21:126. https://doi.org/10.1186/ s10194-020-01192-5.

16. Durán J, Esnaola S, Rubio R, Iztueta A. Obstructive sleep apnea-hypopnea and related clinical features in a population-based sample of subjects aged 30 to $70 \mathrm{yr}$. Am J Respir Crit Care Med 2001;163:685-689. https://doi.org/10.1164/ajrccm.163.3.2005065.

17. Young T, Palta M, Dempsey J, Skatrud J, Weber S, Badr S. The occurrence of sleep-disordered breathing among middle-aged adults. N Engl J Med 1993;328:1230-1235. https://doi.org/10.1056/NEJM199304293281704.

18. Loh NK, Dinner DS, Foldvary N, Skobieranda F, Yew WW. Do patients with obstructive sleep apnea wake up with headaches? Arch Intern Med 1999;159:1765-1768. https://doi.org/10.1001/archinte.159.15.1765.

19. Jensen R, Olsborg C, Salvesen R, Torbergsen T, Bekkelund SI. Is obstructive sleep apnea syndrome associated with headache? Acta Neurol Scand 2004;109:180-184. https://doi.org/10.1046/j.1600-0404.2003.00201.x.

20. Johnson KG, Ziemba AM, Garb JL. Improvement in headaches with continuous positive airway pressure for obstructive sleep apnea: a retrospective analysis. Headache 2013;53:333-343. https://doi.org/10.1111/ j.1526-4610.2012.02251.x.

21. Kallweit U, Hidalgo H, Uhl V, Sándor PS. Continuous positive airway pressure therapy is effective for migraines in sleep apnea syndrome. Neurology 2011;76:1189-1191. https://doi.org/10.1212/WNL. 0b013e318212aad0.

22. Bigal ME, Lipton RB. Obesity is a risk factor for transformed migraine but not chronic tension-type headache. Neurology 2006;67:252-257. https://doi.org/10.1212/01.wnl.0000225052.35019.f9.

23. Peppard PE, Young T, Palta M, Dempsey J, Skatrud J. Longitudinal study of moderate weight change and sleep-disordered breathing. JAMA 2000;284:3015-3021. https://doi.org/10.1001/jama.284.23.3015.

24. Sateia MJ. International classification of sleep disorders-third edition: highlights and modifications. Chest 2014;146:1387-1394. https://doi. org/10.1378/chest.14-0970.

25. Ohayon MM, O'Hara R, Vitiello MV. Epidemiology of restless legs syndrome: a synthesis of the literature. Sleep Med Rev 2012;16:283-295. https://doi.org/10.1016/j.smrv.2011.05.002.

26. Acar BA, Acar T, Alagöz AN, et al. Relationship between primary restless legs syndrome and migraine with aura. Kaohsiung J Med Sci 2016; 32:420-426. https://doi.org/10.1016/j.kjms.2016.06.003.

27. Fernández-Matarrubia M, Cuadrado ML, Sánchez-Barros CM, et al. Prevalence of migraine in patients with restless legs syndrome: a casecontrol study. Headache 2014;54:1337-1346. https://doi.org/10.1111/ head.12382.

28. Gozubatik-Celik G, Benbir G, Tan F, Karadeniz D, Goksan B. The prevalence of migraine in restless legs syndrome. Headache 2014;54:872877. https://doi.org/10.1111/head.12288.

29. Gupta R, Lahan V, Goel D. Primary headaches in restless legs syndrome patients. Ann Indian Acad Neurol 2012;15:S104-S108. https:// doi.org/10.4103/0972-2327.100031.

30. Zanigni S, Giannini G, Melotti R, et al. Association between restless 
legs syndrome and migraine: a population-based study. Eur J Neurol 2014;21:1205-1210. https://doi.org/10.1111/ene.12462.

31. Lucchesi C, Bonanni E, Maestri M, Siciliano G, Murri L, Gori S. Evidence of increased restless legs syndrome occurrence in chronic and highly disabling migraine. Funct Neurol 2012;27:91-94.

32. Aurora RN, Kristo DA, Bista SR, et al. The treatment of restless legs syndrome and periodic limb movement disorder in adults--an update for 2012: practice parameters with an evidence-based systematic review and meta-analyses: an American Academy of Sleep Medicine Clinical Practice Guideline. Sleep 2012;35:1039-1062. https://doi.org/ 10.5665/sleep.1988.

33. Garcia-Borreguero D, Silber MH, Winkelman JW, et al. Guidelines for the first-line treatment of restless legs syndrome/Willis-Ekbom disease, prevention and treatment of dopaminergic augmentation: a combined task force of the IRLSSG, EURLSSG, and the RLS-foundation. Sleep Med 2016;21:1-11. https://doi.org/10.1016/j.sleep.2016.01.017.

34. Blin O, Azulay JP, Masson G, Aubrespy G, Serratrice G. Apomorphineinduced yawning in migraine patients: enhanced responsiveness. Clin Neuropharmacol 1991;14:91-95. https://doi.org/10.1097/00002826199102000-00008.

35. Cerbo R, Barbanti P, Buzzi MG, et al. Dopamine hypersensitivity in migraine: role of the apomorphine test. Clin Neuropharmacol 1997;20: 36-41. https://doi.org/10.1097/00002826-199702000-00004.

36. Volans GN. The effect of metoclopramide on the absorption of effervescent aspirin in migraine. Br J Clin Pharmacol 1975;2:57-63. https:// doi.org/10.1111/j.1365-2125.1975.tb00472.x.

37. Cologno D, Cicarelli G, Petretta V, d'Onofrio F, Bussone G. High prevalence of Dopaminergic Premonitory Symptoms in migraine patients with Restless Legs Syndrome: a pathogenetic link? Neurol Sci 2008;29 Suppl 1:S166-S168. https://doi.org/10.1007/s10072-008-0915-4.

38. Dauvilliers Y, Montplaisir J, Molinari N, et al. Age at onset of narcolepsy in two large populations of patients in France and Quebec. Neurology 2001;57:2029-2033. https://doi.org/10.1212/wnl.57.11.2029.

39. Dahmen N, Kasten M, Wieczorek S, Gencik M, Epplen JT, Ullrich B. Increased frequency of migraine in narcoleptic patients: a confirmatory study. Cephalalgia 2003;23:14-19. https://doi.org/10.1046/j.1468-2982. 2003.00343.x.
40. Dahmen N, Querings K, Grün B, Bierbrauer J. Increased frequency of migraine in narcoleptic patients. Neurology 1999;52:1291-1293. https:// doi.org/10.1212/wnl.52.6.1291.

41. Suzuki K, Miyamoto M, Miyamoto T, et al. The prevalence and characteristics of primary headache and dream-enacting behaviour in Japanese patients with narcolepsy or idiopathic hypersomnia: a multicentre cross-sectional study. PLoS One 2015;10:e0139229. https://doi. org/10.1371/journal.pone.0139229.

42. Scammell TE, Winrow CJ. Orexin receptors: pharmacology and therapeutic opportunities. Annu Rev Pharmacol Toxicol 2011;51:243-266. https://doi.org/10.1146/annurev-pharmtox-010510-100528.

43. Bartsch T, Levy MJ, Knight YE, Goadsby PJ. Differential modulation of nociceptive dural input to [hypocretin] orexin $\mathrm{A}$ and $\mathrm{B}$ receptor activation in the posterior hypothalamic area. Pain 2004;109:367-378. https://doi.org/10.1016/j.pain.2004.02.005.

44. Hoffmann J, Supronsinchai W, Akerman S, et al. Evidence for orexinergic mechanisms in migraine. Neurobiol Dis 2015;74:137-143. https:// doi.org/10.1016/j.nbd.2014.10.022.

45. American Academy of Sleep Medicine. International Classification of Sleep Disorders-Third Edition (ICSD-3). Darien: American Academy of Sleep Medicine, 2014.

46. Bjorvatn B, Pallesen S, Moen BE, Waage S, Kristoffersen ES. Migraine, tension-type headache and medication-overuse headache in a large population of shift working nurses: a cross-sectional study in Norway. BMJ Open 2018;8:e22403. https://doi.org/10.1136/bmjopen-2018-022403.

47. Suzuki K, Miyamoto T, Miyamoto M, et al. Dream-enacting behaviour is associated with impaired sleep and severe headache-related disability in migraine patients. Cephalalgia 2013;33:868-878. https://doi.org/ 10.1177/0333102413477742.

48. Lopez R, Jaussent I, Dauvilliers Y. Pain in sleepwalking: a clinical enigma. Sleep 2015;38:1693-1698. https://doi.org/10.5665/sleep.5144.

49. Casez O, Dananchet Y, Besson G. Migraine and somnambulism. Neurology 2005;65:1334-1335. https://doi.org/10.1212/01.wnl.0000180937. 20774.20.

50. Messina A, Bitetti I, Precenzano F, et al. Non-rapid eye movement sleep parasomnias and migraine: a role of orexinergic projections. Front Neurol 2018;9:95. https://doi.org/10.3389/fneur.2018.00095. 